\title{
An Architecture of E-Marketplace Platform for Agribusiness in Indonesia
}

\author{
Erna Piantari ${ }^{1}$, Herdi Ashaury ${ }^{2}$, Enjun Junaeti ${ }^{3}$, Venkata Harsha Nagalla ${ }^{4}$ \\ \{erna.piantari@upi.edu ${ }^{1}$, herdi.ashaury@lecture.unjani.ac.id ${ }^{2}$, enjun@upi.edu ${ }^{3}$ \} \\ Universitas Pendidikan Indonesia ${ }^{1,3}$ \\ Teknik Informatika, Universitas Jenderal Achmad Yani-Indonesia ${ }^{2}$ \\ University of the Cumberlands, Kentucky - USA ${ }^{4}$
}

\begin{abstract}
The development of information technology has brought an era of new digitalbased creative developments. In Indonesia, agriculture is one of the economic and community welfare which needs to be developed and supported with the information technology. Marketplace is one of the technologies commonly used to support economic growth. This study aims to create an electronic marketplace architecture model that is in accordance with the characteristics of business actors in agribusiness. The marketplace architecture is built based on the architecture of the Next Generation E-Commerce Platform and Agriculture Supply Chain Management.
\end{abstract}

Keywords: Market-Place, Agribusiness, E-Commerce, Agriculture E-Commerce, Agriculture SCM

\section{Introduction}

One of the economic and business bases that develops in Indonesia is agribusiness. Agribusiness is a business in agriculture ranging from downstream to upstream. With Indonesia's fertile natural characteristics, agribusiness is one of the keys to Indonesia's economic potential. However, the problem that occurs in agribusiness is agricultural supply chains that are still conventional. The agricultural products usually are not directly distributed to markets or consumers. Agricultural products are bought first by third parties, then sold to consumers on the market. Farmers if want to sell the products themselves, they have to reach the place with a lot of effort. Since they need to go to the place along with a large scale of product. They need a special transportation to go. In addition, some agricultural products have a very short expiration time. It makes farmer difficult to plan their production and manage it supply. This condition force farmers to sell their product to third parties, Sometimes the selling price to third parties is very small, so farmers suffer losses. It's better rather than suffer losses from rotten products. This condition make farmers disadvantages in the supply chain and income growth [1].

Digital economy can be a great potential for answering the problems of conventional agribusiness supply chains [2]. The rapidly growth of information technology has created more e-commerce activities in Indonesia [3]. This development has brought a new era of creative economy based on digital that enables digital commercial activities through the internet network. E-commerce defined as a commercial activity (sale-purchase transaction) that occurs online [4]. E-commerce allows a shop owner to sell his products to buyers without 
having to meet directly [4].The broad reach offered by e-commerce can cut supply chains from producers to consumers, so that the transaction runs faster [3].

Currently the development of e-commerce in Indonesia transformed into more complex ecommerce activities, namely e-marketplace activities. E-marketplaces have a very important role in e-commerce that is can reduce transaction and searching costs, high efficiency with automated transactions, and enhance the economic improvement by the intermediation effect [2]. The existence of e-marketplaces has made marketing reach wider than ordinary ecommerce. Based on Indonesia startup top list in startupranking.com, e-marketplace always rank first in that list. Four of the top six are e-commerce applications that three of them are emarketplaces. This gives a picture of the great potential possessed by e-commerce including emarketplace.

Several e-commerce systems for agribusiness has developed in Indonesia. However, the existence of the agriculture e-commerce is still not widely known by the public so that the potential of agriculture e-commerce still not maximized [3]. There are several problems including e-commerce for agribusiness in Indonesia that has not transformed into an agribusiness e-marketplace, whereas the characteristics of the Indonesian people prefer to transact in general e-marketplaces that offer prices that are more competitive. In addition, agriculture products are perishable products, which result in complex logistics handling [5]. The community still chooses to buy agricultural products directly, especially for fruits and vegetables, to get fresher products. However, the development of the agribusiness economy must remain at odds with the current state of the digital economy. With the potential for a growing digital economy, the optimism of e-commerce growth for agribusiness is still very good [3].

However, with the problems that characterize the agribusiness, an e-commerce form needed that allows transactions tailored to the characteristics and problems of the agribusiness. The transformation of e-commerce into an e-marketplace for agribusiness also needed. Therefore, this research will design an e-marketplace architecture for agribusiness. So that our contribution is an architecture design of e-marketplace that can be implement for agribusiness in Indonesia.

\section{Literature Review}

\subsection{E-Commerce}

E-commmerce referred to online trade is the activity of buying, selling, marketing goods or services through electronic device [6]. E-Commerce can do many activities without involving a lot of humans because it can work automatically or by itself, such as receiving orders, determining the stock of products, receiving payments, and so on [6].

E-commerce is a dynamic set of technology, applications and business processes that connect companies, consumers and communities through electronic transactions and the exchange of electronic products, services and information [6]. 


\subsection{E-Marketplace}

E-Marketplace or often known as an online marketplace is a system designed to bring together sellers and buyers. This system is designed by stopping its place, but still realizing the processes that usually occur in it with the aim of reducing costs [7].

\subsection{Supply Chain Managent (SCM)}

Supply chain management (SCM) is defined as a sequence of activities that aims to help meet the needs of consumers by supporting the management of activities that change the initial material into semi-finished goods or ready-made goods. This SCM also regulates the distribution process to consumers, so that the activities in SCM include the traditional transaction function plus other activities that connect suppliers with distributors and consumers [8]. Figure 1 is a schematic diagram that illustrates in general the SCM process.

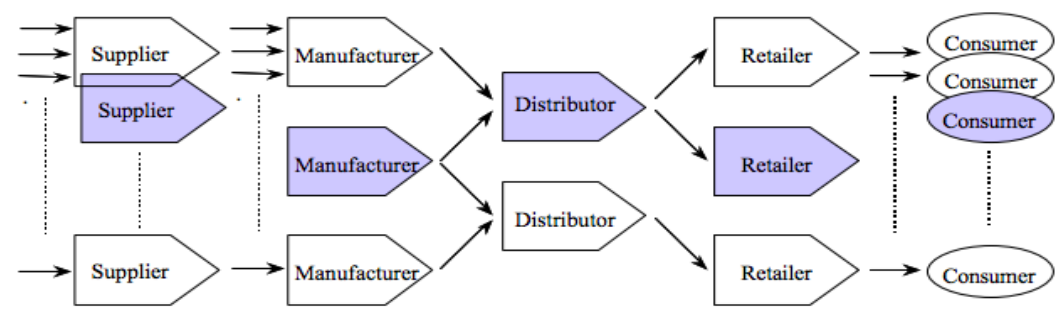

Fig. 1. SCM Diagram [8]

SCM Agriculture. SCM for agriculture has its own characteristics. Specifically, SCM agriculture can be divided into 3 bases, namely middleman-base, cooperative-base, and vertical-base. The step for each SCM agriculture base shown in Figure 2.

\subsection{Business Model}

Business model is a form of transaction in a business process. There are several differences in business models and business models are often used in e-commerce business models [9]. There is four business Model [6],[9]:

a) Business To Business (B2B), is a business models of trade transactions between businesses, such as between a producer and wholesaler, or between a wholesaler and retailer.

b) Business To Customer (B2C), is a business activities that serve end customers with products and / or services.

c) Customer To Business (C2B), is a trading business model where consumers offer products and services to companies and companies pay for them.

d) Customer To Customer (C2C), is a business models that involve transactions that connect consumers through third party services. 




Fig. 2. Traditional SCM agriculture.

\section{Architecture of Agribusiness E-marketplace}

In this research, an e-marketplace architecture will be designed specifically for agribusiness. The development of the agribusiness e-marketplace must be able to adjust the conventional agribusiness SCM. In accordance with the literature study that has been done that supply chain management for agribusiness has certain criteria. This criterion is a challenge in developing the agribusiness e-marketplace architecture. To gather the information and picture about the agribusiness process, we observed the traditional SCM of agribusiness in Bandung, West Java.

Based on the identification of observations result and the traditional agribusiness SCM process in Figure 2, it can be determined that there are three main actors involved, namely customers, retailers and wholesalers. As for the supplier actor, it can be categorized into two categories, namely farmers and household farmers. From the results of the identification, an agribusiness e-commerce framework was built.

Figure 3 shows the identification of agribusiness actor in traditional agribusiness SCM.

Figure 4 shows the agribusiness architecture for the e-marketplace. The business model chosen in this e-marketplace architecture is a combination of the $\mathrm{C} 2 \mathrm{C}, \mathrm{B} 2 \mathrm{C}, \mathrm{C} 2 \mathrm{~B}$ and $\mathrm{B} 2 \mathrm{~B}$ business models. The choice of this business model is in line with E-marketplace trends in Indonesia.

By combining $\mathrm{C} 2 \mathrm{C}, \mathrm{B} 2 \mathrm{C}, \mathrm{C} 2 \mathrm{~B}$ and $\mathrm{B} 2 \mathrm{~B}$ business processes, the problem that occurs is a more complex logistics chain with different transaction characteristics. From the results of the analysis, it can identified that there are four transactions:

1. Farmers to industry, wholesaler to industry
a. Big party
b. Well plan
c. Middle reach 
d. Tends to be comprehensive transaction times

e. Tend to be predictable

f. Product quality through fairly clear quality control

g. Low price

2. Household farmer to household, store to household

a. Selling product per item

b. Happen without plan, unpredictable

c. Need fast response and fast transaction

d. Frequency of the transaction is high

e. Competitive price

3. Farmers to household, wholesaler to household
a. Selling limit product
b. Unpredictable
c. Fast transaction
d. Frequency is fear
e. Competitive price

4. Household farmers to industry, store to industry

a. Well plan

b. Tend to be predictable

c. Product quality through fairly clear quality control Farmers to Industry,

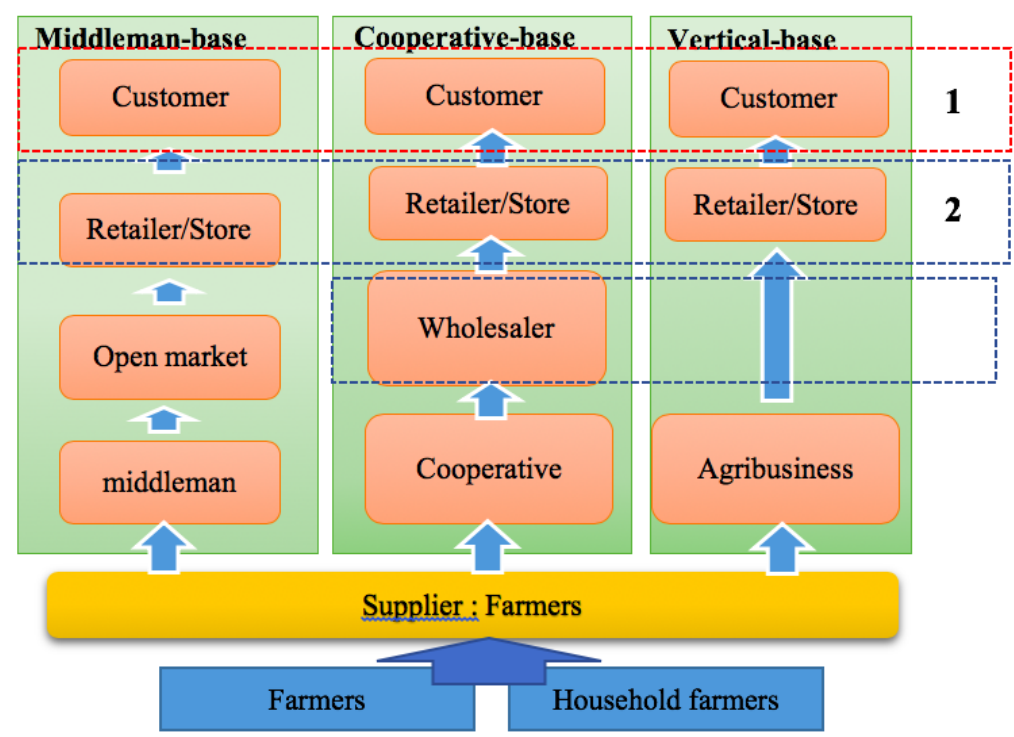


Fig. 3. Identification agribusiness actor in traditional agribusiness SCM.

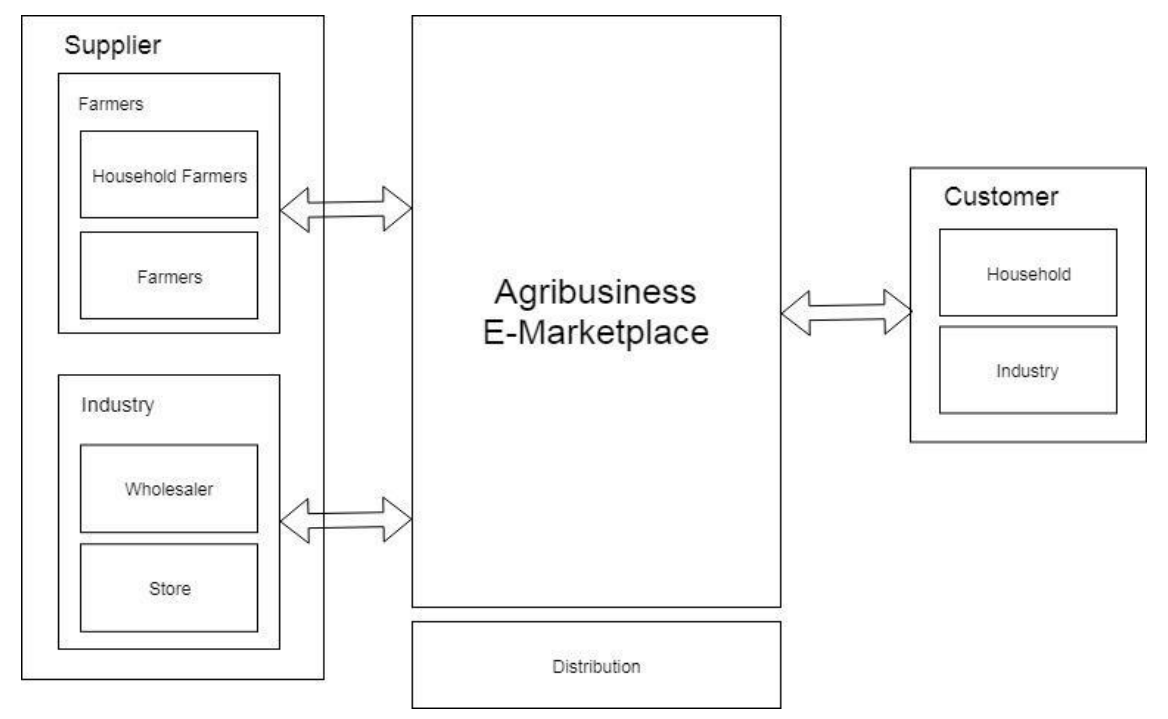

Fig. 4. Architecture of agribusiness e-marketplace

\section{Conclusion}

Based on the analysis of economic and market trends, currently the economy in Indonesia is dominated by transaction activities that run online through various platforms, and the fastest growing transaction platform is e-marketplace. In line with this trend, then in this paper, we design an architecture of e-marketplace for agribusiness. The business model implemented in the architecture that is built is a combination of $\mathrm{B} 2 \mathrm{~B}, \mathrm{~B} 2 \mathrm{C}, \mathrm{C} 2 \mathrm{~B}$ and $\mathrm{C} 2 \mathrm{C}$. By analyzing the characteristics of the SCM argiculture, the most important thing to consider in building this architecture is the distrubution process. The distribution process provided in this emarketpalce differs depending on the business process carried out. From the results of the analysis obtained 4 distribution services that must be available in the agriculture emarketplace.

Acknowledgments. This work was supported by LPPM Universitas Pendidikan Indonesia.

\section{References}

[1] Wiggins, S. \&. Kirsten, J. \&. Llambi, L.: The Future of Small Farms, World Development. Elsevier, pp. 1341-1348 (2010)

[2] Choi, T. -M., Li D., Yan, H.: Optimal returns policy for supply chain with e-marketplace. 
International Journal of Production Economics. zv. 88, \%1. vyd.2, pp. 205-227, 2004.

[3] Machfud, A. K. and Kartiwi, M.: E-commerce Adoption by Indonesian Small Agribusiness: Reconsidering the Innovation-Decision Process Model. International Conference on Information and Communication Technology for the Muslim World (ICT4M), zv. 5, \%1. vyd.1, pp. 1-6 (2013)

[4] Laudon, K. C. and Traver, C. G.: E-Commerce: Business, Technology. Society 3rd ed., Prentice Hall (2007)

[5] Costopoulou, C. I. and Lambrou, M. A.: An architecture of Virtual Agricultural Market systems: The case of trading perishable agricultural products. Journal Information Services and Use, pp. 39-48, (2000)

[6] Baum, D.: E-Commerce. New Jersey: Oracle Corp (1999)

[7] Luca, M.: Designing Online Marketplaces: Trust and Reputation Mechanisms. Innovation Policy and the Economy. zv. 17, \%1. vyd.1, pp. 77-93 (2017)

[8] Vorst, J. V. D.: Supply Chain Management : Bridging Theory and Practice. London: Reed Business (2004)

[9] Shafik, N.: The Future of Development Finance. rev. Center for Global Develeopment, Washington, D.C, Center for Global Development. pp. 250 (2011) 